\title{
INFLUENCE OF SESTON QUANTITY AND QUALITY ON GROWTH OF TROPICAL CLADOCERANS
}

\author{
FERRÃO-FILHO, A. S., ARCIFA, M. S. and FILETO, C. \\ Departamento de Biologia, FFCLRP, Universidade de São Paulo, Av. Bandeirantes, 3900, \\ CEP 14040-901, Ribeirão Preto, SP, Brazil \\ Correspondence to: Marlene Sofia Arcifa, Laboratório de Limnologia, Departamento de Biologia, \\ FFCLRP, Universidade de São Paulo, Av. Bandeirantes, 3900, CEP 14040-901, Ribeirão Preto, SP, \\ Brazil, e-mail: marcifa@usp.br \\ Received April 29, 2003 - Accepted October 28, 2003 - Distributed February 28, 2005 \\ (With 7 figures)
}

\begin{abstract}
The seston of the small, shallow, and tropical lake Monte Alegre was tested for quantity and quality for cladocerans by growth bioassays, which were carried out in spring (Daphnia gessneri and Moina micrura), summer (D. gessneri, M. micrura, Ceriodaphnia cornuta, and Simocephalus mixtus), and winter (D. gessneri and D. ambigua). Cohorts of newborns originating from ovigerous females collected in the lake or from laboratory cultures were submitted, at a room temperature of $23^{\circ} \mathrm{C}$ to the following treatments: (1) the chlorophytes Ankistrodesmus falcatus and/or Scenedesmus spinosus; (2) lake seston; and (3) lake seston + chlorophytes. Growth rate, clutch size, and fecundity were evaluated. Seston alone was not the best food for promoting cladoceran growth. There were seasonal differences in food quantity and quality with spring and summer seston being better for growth than that of the winter. Adding chlorophytes to the seston increased clutch size and fecundity for most species in summer and winter, but not in spring. Energy limitation seems to be the most important factor influencing cladoceran growth in summer and especially in winter.
\end{abstract}

Key words: tropical cladocerans, growth bioassays, food quantity and quality.

\section{RESUMO}

\section{Influência da quantidade e qualidade do séston sobre o crescimento de cladóceros tropicais}

O séston do lago Monte Alegre, um lago tropical pequeno e raso, foi testado em relação à quantidade e qualidade para os cladóceros por meio de experimentos de crescimento realizados na primavera (Daphnia gessneri e Moina micrura), no verão (D. gessneri, M. micrura, Ceriodaphnia cornuta e Simocephalus mixtus) e no inverno (D. gessneri e D. ambigua). Coortes de recém-nascidos oriundos de fêmeas ovígeras coletadas no lago ou de culturas de laboratório foram submetidas à temperatura de $23^{\circ} \mathrm{C}$ aos seguintes tratamentos: (1) as clorofíceas Ankistrodesmus falcatus e/ou Scenedesmus spinosus, (2) séston do lago e (3) séston + clorofíceas. Foram avaliados a taxa de crescimento, o tamanho da ninhada e a fecundidade. O séston sozinho não foi o melhor alimento para promover o crescimento dos cladóceros. Houve diferenças sazonais quanto à quantidade e à qualidade do alimento, sendo o séston da primavera e o do verão melhores para promover o crescimento que o do inverno. A adição de clorofíceas ao séston aumentou o tamanho da ninhada e a fecundidade para a maioria das espécies no verão e no inverno, mas não na primavera. A limitação de energia parece ser o fator mais importante para o crescimento de cladóceros no verão e, especialmente, no inverno.

Palavras-chave: cladóceros tropicais, experimentos de crescimento, quantidade e qualidade do alimento. 


\section{INTRODUCTION}

The study of food quality for zooplankton has recently progressed considerably, mainly in the temperate zone (revisions by Gulati \& DeMott, 1997, and Sterner \& Schulz, 1998) compared to the tropics (Bozelli, 1998; Pinto-Coelho, 1998; Ferrão-Filho et al., 2000; Nandini, 2000). As the dynamics of plankton communities in the tropical zone may be very different from that in the temperate one, different patterns in the interaction between phytoplankton and zooplankton can also be expected. Furthermore, tropical cladoceran species are generally smaller than their temperate counterparts, so that interactions can have particular characteristics in tropical communities.

Size, shape, and digestibility of algae are points that have been cited as limiting food quality for herbivores (Burns, 1968; Lampert, 1987; Gulati \& DeMott, 1997; Kurmayer, 2000, 2001). Included in such factors are P-limitation and deficiency in essential polyunsaturated fatty acids (PUFA). The P-limitation hypothesis predicts that zooplankton growth would be limited if the molar C:P ratio of available food exceeds some threshold ratio (around 300), particularly for Daphnia (Urabe \& Watanabe, 1992; Sterner \& Schulz, 1998; Elser et al., 2001). Algae deficiency in PUFA has also been proposed for explaining poor growth of zooplankton (MüllerNavarra, 1995; DeMott \& Müller-Navarra, 1997). However, most studies on the role of phosphorus and the PUFA limitation have been undertaken with zooplankton fed on algal cultures in laboratory experiments. Although there is evidence that zooplankton can be limited by phosphorus (DeMott \& Gulati, 1999; DeMott et al., 2001; Boersma et al., 2001; Elser et al., 2001) and PUFA in nature (Müller-Navarra, 1995; Müller-Navarra et al., 2000; Wacker \& von Elert, 2001), more studies on the limiting effect of natural food, as well as on other algae constraints, are needed (Gulati \& DeMott, 1997; DeMott \& Tessier, 2002).

Since 1985 several studies have been undertaken in lake Monte Alegre for the purpose of characterizing the ecosystem and formulating hypotheses on interactions (Arcifa, 1999). Arcifa et al. (1992) analyzed the factors limiting zooplankton growth in lake Monte Alegre, with food quantity and/or quality emerging as the main factor in the cool-dry season, and Chaoborus predation in the warm-wet season. Phytoplankton fractions and seston quantity and quality have been tested for their effects mainly on reproduction of cladocerans in the lake (Fileto et al., 2004; Ferrão-Filho et al., 2003), in addition to the effects of predation by Chaoborus and planktonic Hydracarina (Castilho-Noll, 2002; Cassano et al., 2002).

In this study, the potential limitation by seston in lake Monte Alegre was tested using growth bioassays with the cladocerans Ceriodaphnia cornuta Sars, Daphnia ambigua Scourfield, D. gessneri Herbst, Moina micrura Kurz, and Simocephalus mixtus Sars submitted to treatments with seston, seston supplemented with edible chlorophytes, and chlorophytes alone. Experiments were carried out in spring (November 1998), summer (February 1999), and winter (July 1999), along with analysis of sestonic $\mathrm{C}, \mathrm{N}$, and $\mathrm{P}$, and phytoplankton composition and size, in order to raise hypotheses on factors possibly constraining cladoceran growth in the lake in different seasons.

\section{Study area}

Lake Monte Alegre $\left(21^{\circ} 11^{\prime} \mathrm{S}, 47^{\circ} 43^{\prime} \mathrm{W}\right)$ is a small $($ area $=7 \mathrm{ha})$, shallow $\left(Z_{\max }=5 \mathrm{~m}\right)$, eutrophic, and warm discontinuous polymictic reservoir, located in the State of São Paulo, southern Brazil. Its stratification during summer leads to oxygen depletion near the bottom (Arcifa et al., 1990). As the outlet is superficial and the dam is not manipulated by man, it functions as a small lake, having a retention time of about 45 days at the end of the wet season. The region is characterized by a tropical climate, with a marked dry-cool season (May-September) and a wet-warm season (October-April). The average surface temperature was $28.5^{\circ} \mathrm{C}$ in the spring of 1998 , and $30.5^{\circ} \mathrm{C}$ in the summer and $23^{\circ} \mathrm{C}$ in the winter of 1999 .

Cyanobacterial blooms are uncommon in the lake, despite its eutrophic condition (Silva, 1995). Eight planktonic cladoceran species have been recorded in four year-long studies (1985-86, 198889, 1999, and 2001-02) at the lake (Arcifa et al., 1992, 1998; Fileto, 2001; Bunioto, 2003): Bosmina tubicen, Ceriodaphnia cornuta, C. richardi, Daphnia ambigua, D. gessneri, Diaphanosoma birgei, Moina micrura, and M. minuta. From 1998 to 2001, the most frequent and sometimes the most abundant were $D$. gessneri and D. ambigua (max. densities 100, 80 ind $\mathrm{L}^{-1}$, respectively). 


\section{MATERIALS AND METHODS}

\section{Seston analyses}

Water samples were collected in the deepest region of the lake, using a bilge pump (Model 34600-0000, Jabsco ITT Ind., Costa Mesa, USA) delivering $30 \mathrm{~L} \mathrm{~min}^{-1}$ and integrating the water column in a $5 \mathrm{~L}$ container. In the laboratory, subsamples of 500 and $1000 \mathrm{ml}$ were filtered in glass fiber filters (Sartorius AG 37070, Goettingen, Germany) for the analysis of particulate organic carbon (Strickland \& Parsons, 1972), nitrogen (Kjedahl method, Mackereth et al., 1978), particulate phosphorus (Fassbender, 1973), and chlorophyll $a$ (Lorenzen, 1967). Phytoplankton was counted according to Utermöhl (1958) and carbon content of algae was calculated as $10 \%$ of their biovolume (Vollenweider, 1974). Phytoplankton species composition was analyzed and, according to algae size, separated in the fractions $<20$ and $\geq 20 \mu \mathrm{m}$. Algae groups and size fractions were represented in terms of algal carbon.

\section{Algae and cladoceran cultures}

The green algae used as food for cladocerans, Ankistrodesmus falcatus (Braun) (length $40 \mu \mathrm{m}$ ) and Scenedesmus spinosus R. Chodat (length $14 \mu \mathrm{m})$, were cultivated in MBL medium (Stemberger, 1981) in an incubation chamber (model $347 \mathrm{CDG}, \mathrm{FANEM}, \mathrm{SP}, \mathrm{Brazil})$ at $23^{\circ} \mathrm{C}$ and using a 12L:12D photoperiod cycle. The same temperature and light conditions were used in the experiments and in maintaining the cladoceran cultures.

Cladocerans were collected in the lake with a $60 \mu \mathrm{m}$ mesh-size net and kept for several generations in the laboratory in 500 and $1000 \mathrm{ml}$ stoppered bottles (Schott, Germany) with lake water filtered in glass fiber filters. They were fed $1.0 \mathrm{mg} \mathrm{C} \mathrm{L}^{-1}$ of $A$. falcatus or $S$. spinosus algae chosen because previous tests had indicated their suitability for promoting the best growth rates for most cladocerans. As Moina micrura grew better with $A$. falcatus, this alga was used as the sole food source for this species.

\section{Growth bioassays}

Growth bioassays were carried out in spring (11-17/XI/98) with Daphnia gessneri $(1.16 \mathrm{~mm})$ and Moina micrura (0.85 mm); in summer (21-27/II/99) with Ceriodaphnia cornuta $(0.45 \mathrm{~mm})$, Daphnia gessneri, Moina micrura, and Simocephalus mixtus (1.40 mm); and in winter (01-07/VII/99) with Daphnia ambigua $(0.90 \mathrm{~mm})$ and Daphnia gessneri. These species were chosen as representative of the cladocerans of the lake and for testing different-sized organisms. However, as a large number of individuals per species was necessary for the experiments, the cladocerans used varied according to their availability in the cultures or in the lake.

Cohorts originating from ovigerous females $(D$. gessneri and D. ambigua) collected in the lake, when the necessary number of individuals not reached in the cultures, and from laboratory cultures for the other species were used in the experiments. At the beginning of the experiments, about 10 neonates were placed in pieces of small pre-tared aluminum foil, dried at $60^{\circ} \mathrm{C}$, and weighed in a microbalance (model UMT2, Mettler Toledo, Greifensee, Switzerland) to the nearest $0.1 \mu \mathrm{g}$. Initially, 20 animals of each species were placed in $500 \mathrm{ml}$ stoppered bottles for each treatment. Every other day, the animals were transferred to new algal suspensions and 10 individuals (day 2) and 5 (at the end of the experiment) of each replicate were weighed on a small piece of aluminum foil and then discarded. Treatments in the spring were: (1) Ankistrodesmus falcatus alone, (2) seston, and (3) seston + chlorophyte. In the summer treatments were: (1) chlorophytes (A. falcatus for M. micrura and Scenedesmus spinosus for the other species), (2) seston, and (3) seston + chlorophytes. In the winter treatments were: (1) S. spinosus alone, (2) seston, and (3) seston + chlorophyte. Chlorophytes were offered alone at a concentration of $1.0 \mathrm{mg} \mathrm{C} \mathrm{L}^{-1}\left(\mathrm{ca} .3 \times 10^{7}\right.$ cells.ml ${ }^{-1}$ for $S$. spinosus and $3 \times 10^{4}$ cells.ml ${ }^{-1}$ for $A$. falcatus) or mixed with seston at a concentration of $0.5 \mathrm{mg} \mathrm{C} \mathrm{L}{ }^{-1}$. Three replicate bottles were used per treatment; the average individual biomass was obtained using groups of animals removed from each of the three bottles. The exponential growth rate was calculated by the equation:

$$
\mathrm{g}=\left[\ln \left(\mathrm{W}_{\mathrm{t}}\right)-\ln \left(\mathrm{W}_{\mathrm{o}}\right)\right] / \mathrm{t}
$$

where:

$\mathrm{W}_{\mathrm{o}}$ and $\mathrm{W}_{\mathrm{t}}$ are the animals' average weight at time 0 and after $t$ days, respectively.

Growth rates were evaluated only during the pre-reproductive period of the cladocerans, which lasted 2 days for Moina micrura (although Figs. 2 and 3 show 4 days for standardization purposes) and 4 days for the other species. However, the experiments lasted 5-6 days in order to record the number of eggs produced, which was necessary for 
calculating clutch size (number of eggs produced by the ovigerous females) and fecundity (total of eggs produced by the total of females).

The purpose of the addition of edible chlorophytes to the seston was to test for any food limitation in the lake seston. If cladocerans improved growth in the seston plus chlorophytes, as opposed to seston alone, this would indicate that lake seston quantity and/or quality were limiting. Growth rate differentials were calculated by subtracting growth rate in the seston treatment from growth rate in seston + chlorophytes. According to DeMott et al. (2001), growth rate differentials are the best way of estimating the effect of food limitation.

Chlorophyte feeding treatments were excluded from the statistical analyses since they could not be considered as controls for seston. In this case, seston treatments were considered controls and the effects of green algae additions were estimated as growth differentials. Growth with chlorophytes alone was an estimate of growth rates with suitable algae used for culturing cladocerans in the laboratory.

\section{RESULTS}

Sestonic elemental analyses, chlorophyll $a$, and phytoplankton composition

Higher concentrations of carbon (C) and chlorophyll $a$ were found in spring and summer (Table 1). Nitrogen and phosphorus were measured only in summer and winter. Phosphorus concentration and $\mathrm{C}: \mathrm{P}$ ratio were higher in winter and in summer, respectively. Higher values of nitrogen concentration and $\mathrm{C}: \mathrm{N}$ ratio were found in summer and in winter, respectively.

In spring, Zygnemaphyceae, Chlorophyceae, and Euglenophyceae contributed most to the phytoplankton carbon (Fig. 1A). In summer, the importance of Euglenophyceae and Cryptophyceae increased, with dinophyceans virtually disappearing. In winter, phytoplankton diversity was lower than in the previous seasons, increasing the contribution of Dinophyceae and Chlorophyceae, which together comprised $75 \%$ of the algal carbon, while Cryptophyceae contributed the remaining $25 \%$.

The average algal carbon was $c a .0 .35,0.06$, and $0.04 \mathrm{mg} \mathrm{C} \mathrm{L}^{-1}$, in spring, summer, and winter, respectively. Nanoplankton contribution $(<20 \mu \mathrm{m})$ to the algal carbon was $c a .0 .16,0.026$, and 0.023 $\mathrm{mg} \mathrm{C} \mathrm{L}{ }^{-1}$ in the same seasons. In spring and summer, microplankton $(\geq 20 \mu \mathrm{m})$ carbon dominated the phytoplankton, whereas in winter the nanoplanktonic fraction was the most important despite a higher contribution of dinophyceans (Fig. 1B).

\section{Growth bioassays}

In spring (Fig. 2), the addition of the chlorophyte to seston improved growth rates of both cladocerans, although significant differences between treatments were found only for Moina micrura (Table $2 ; \mathrm{p}=0.03$ ). In summer (Fig. 3), Daphnia gessneri, Simocephalus mixtus, and Ceriodaphnia cornuta experienced a significant improved growth when chlorophytes were added to seston (Table $2: \mathrm{p}=0.02$, $\mathrm{p}=0.003, \mathrm{p}=0.05$, respectively). For M. micrura, growth rates were nearly the same in both treatments. Thus, summer seston was unable to promote the best growth for most species. In winter (Fig. 4), there were significant improvements again in growth rates of $D$. gessneri and D. ambigua when seston was mixed with chlorophytes (Table 2: $\mathrm{p}=0.001$ and $p=0.015$, respectively). Therefore, lake seston was generally not the best food for promoting growth. These results indicated that cladoceran growth was more affected by lake seston in winter than in the warm seasons (spring and summer), as is also shown by the higher growth rate differential in winter for D. gessneri (Fig. 5).

TABLE 1

Average concentrations $( \pm \mathrm{SD})$ of carbon $(\mathrm{C})$, nitrogen $(\mathrm{N})$, phosphorus (P), and chlorophyll $a$ in the seston. C:N and $\mathrm{C}: \mathrm{P}$ are molar ratios.

\begin{tabular}{|c|c|c|c|c|c|c|}
\hline Season & $\begin{array}{c}\mathbf{C} \\
\left(\mathbf{m g ~ L} \mathbf{~ L}^{-\mathbf{1}}\right)\end{array}$ & $\begin{array}{c}\mathbf{N} \\
\left(\mathbf{m g ~ L}^{-\mathbf{1}}\right)\end{array}$ & $\begin{array}{c}\mathbf{P} \\
\left(\boldsymbol{\mu} \mathbf{g ~ L}^{-\mathbf{1}}\right)\end{array}$ & $\mathbf{C : \mathbf { N }}$ & $\mathbf{C : P}$ & $\begin{array}{c}\text { Chlorophyll } \boldsymbol{a} \\
\left(\boldsymbol{\mu g} \mathbf{~ L}^{\mathbf{1}}\right)\end{array}$ \\
\hline Spring & $0.72 \pm 0.00$ & - & - & - & - & $16.29 \pm 4.04$ \\
\hline Summer & $1.03 \pm 0.09$ & $0.31 \pm 0.08$ & $3.80 \pm 0.06$ & $3.95 \pm 0.64$ & $703.00 \pm 52.32$ & $12.55 \pm 1.68$ \\
\hline Winter & $0.20 \pm 0.006$ & $0.020 \pm 0.003$ & $15.56 \pm 2.05$ & $11.77 \pm 1.40$ & $32.47 \pm 4.10$ & $4.14 \pm 1.60$ \\
\hline
\end{tabular}



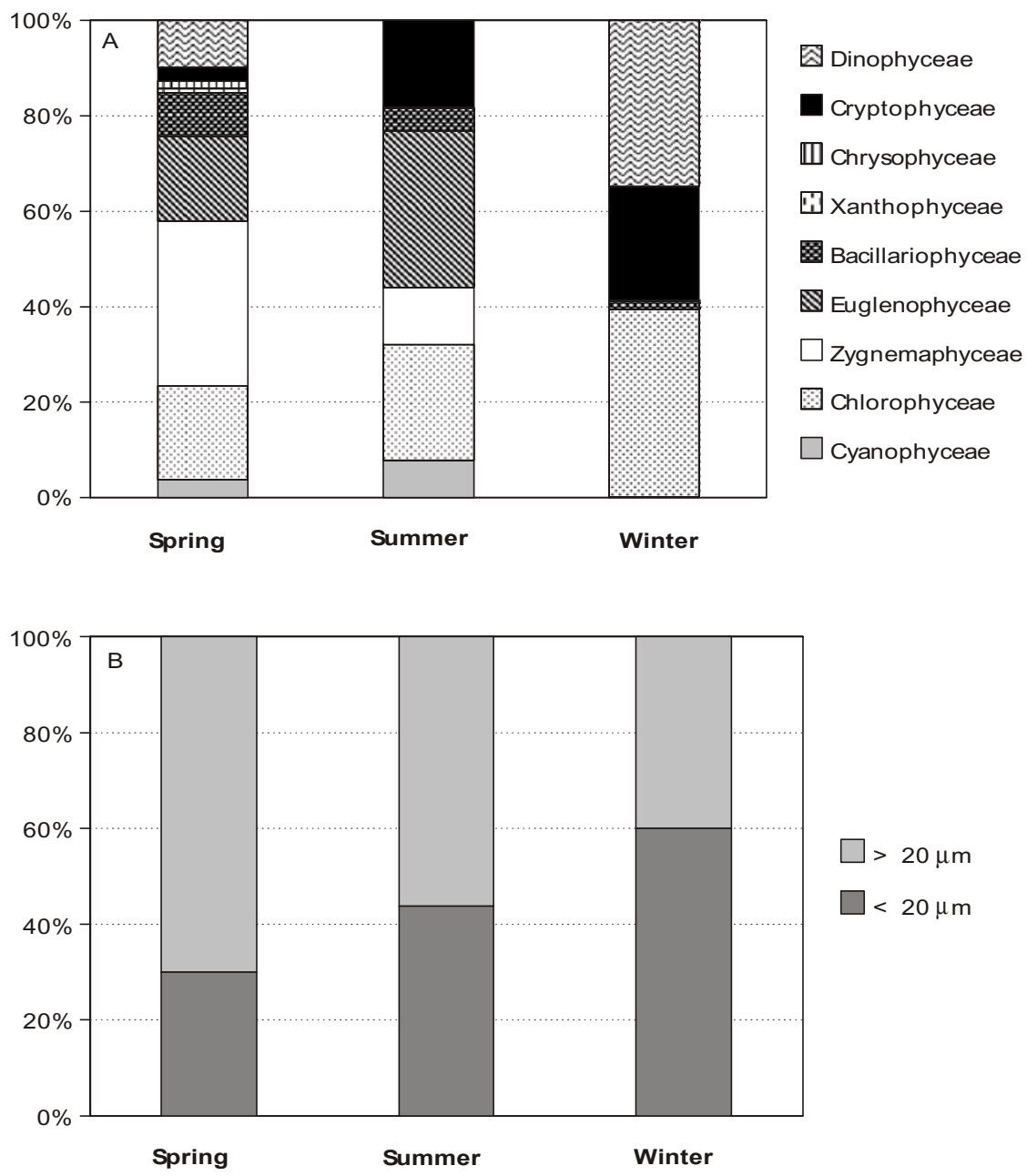

Fig. 1 - Composition (A) and size fraction (B) of phytoplankton in lake Monte Alegre in the three seasons studied. Data are expressed as percent carbon, based on biovolume of algae.

Statistical differences appeared between treatments in each season (Table 3). Except in summer, in the other seasons there were no statistical differences among species, with most species responding in a similar way to green algae additions. Only $M$. micrura showed a consistently higher growth rate for both treatments, which was responsible for the difference between the species in summer (Table 3). A comparison of species $v s$. treatments showed no significant interaction in any season.

\section{Clutch size and fecundity}

In spring, similarly to growth, the addition of the chlorophyte to seston significantly improved clutch size and fecundity of M. micrura (Fig. 6). As occurred for growth, there was no difference between clutch size and fecundity in both treatments for D. gessneri. In summer, the addition of chlorophytes to seston significantly improved clutch size and fecundity of all cladoceran species, except for $D$. gessneri despite its higher growth rate with 
food supplement. In winter, paralleling data on growth, clutch size and fecundity of both Daphnia species were significantly improved with the addition of chlorophytes to seston.
Only in summer did clutch size and fecundity coincide in both treatments for most species, meaning that the majority of females produced eggs at the end of the experiment.

TABLE 2

Juvenile growth rates $( \pm$ SD) of cladocerans in different treatments (Two-sample t-test, $\boldsymbol{\alpha}=\mathbf{0 . 0 5})$.

\begin{tabular}{|c|c|c|c|}
\hline \multirow{3}{*}{ Cladoceran } & \multicolumn{2}{|c|}{ Treatments } & \multirow{3}{*}{$\mathbf{p}$} \\
\hline & Seston & Seston + chloro & \\
\hline & \multicolumn{2}{|c|}{ Spring } & \\
\hline D. gessneri & $0.22 \pm 0.067$ & $0.31 \pm 0.036$ & 0.116 \\
\hline \multirow[t]{2}{*}{ M. micrura } & $0.20 \pm 0.043$ & $0.29 \pm 0.016$ & 0.030 \\
\hline & \multicolumn{2}{|c|}{ Summer } & \\
\hline C. cornuta & $0.17 \pm 0.051$ & $0.31 \pm 0.070$ & 0.047 \\
\hline D. gessneri & $0.23 \pm 0.018$ & $0.33 \pm 0.041$ & 0.020 \\
\hline M. micrura & $0.57 \pm 0.055$ & $0.58 \pm 0.040$ & 0.863 \\
\hline \multirow[t]{2}{*}{ S. mixtus } & $0.24 \pm 0.008$ & $0.33 \pm 0.023$ & 0.003 \\
\hline & \multicolumn{2}{|c|}{ Winter } & \\
\hline D. ambigua & $0.20 \pm 0.062$ & $0.41 \pm 0.065$ & 0.015 \\
\hline D. gessneri & $0.17 \pm 0.016$ & $0.35 \pm 0.026$ & 0.001 \\
\hline
\end{tabular}
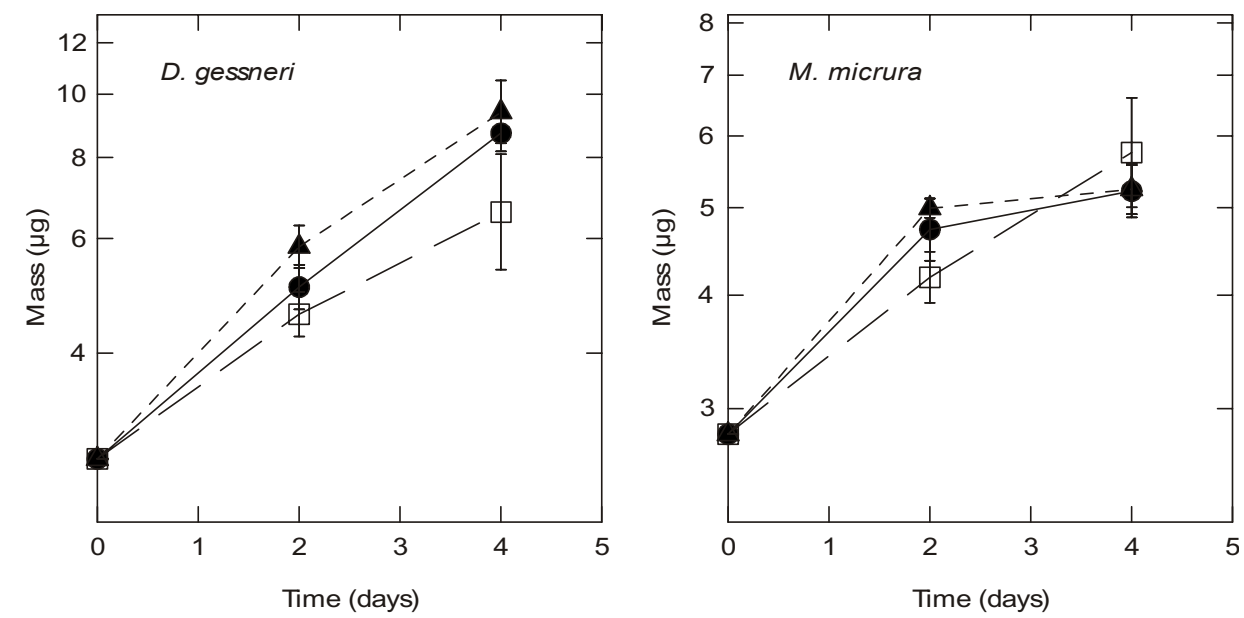

Fig. 2 - Growth bioassay carried out in spring with the cladocerans D. gessneri and M. micrura in three treatments: (•) Chlorophyte (Ankistrodesmus falcatus; $\left.1.0 \mathrm{mg} \mathrm{C} \mathrm{L})^{-1}\right) ;(\square)$ seston and $(\boldsymbol{\Delta})$ seston + chlorophyte $\left(0.5 \mathrm{mg} \mathrm{C} \mathrm{L}^{-1}\right)$. 

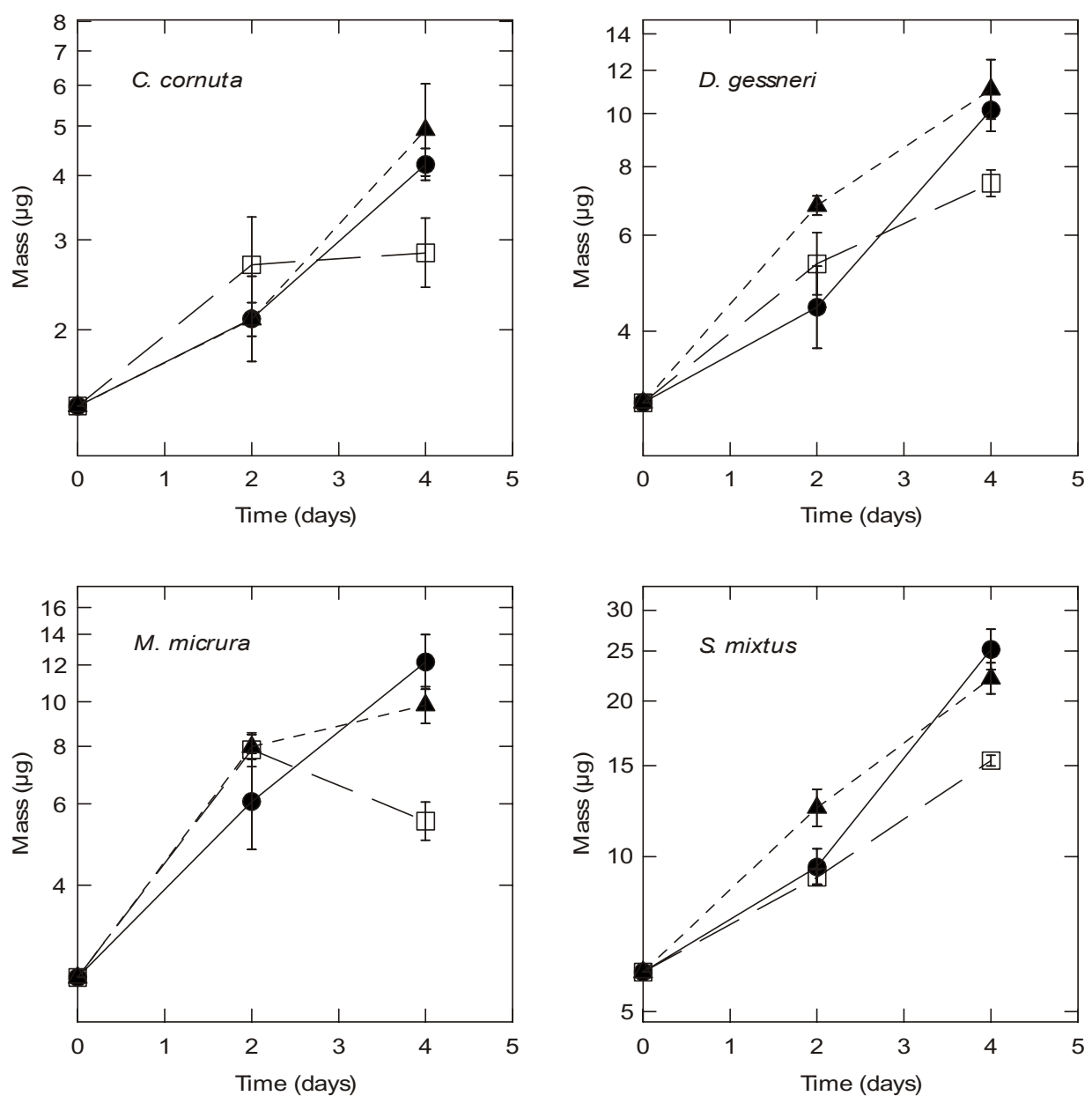

Fig. 3 - Growth bioassay carried out in summer with the cladocerans C. cornuta, D. gessneri, M. micrura, and S. mixtus in three treatments: $(\bullet)$ Chlorophytes (Ankistrodesmus falcatus or Scenedesmus spinosus; $\left.1.0 \mathrm{mg} \mathrm{C} \mathrm{L}^{-1}\right)$; ( $\square$ ) seston and $(\bullet)$ seston + chlorophytes. M. micrura was fed A. falcatus and other cladocerans S. spinosus. Both chlorophytes were added to seston at a total concentration of $0.5 \mathrm{mg} \mathrm{C} \mathrm{L}^{-1}$.

\section{DISCUSSION}

Considering that growth differentials may be a measure of any kind of food limitation for individual growth (DeMott et al., 2001), population growth differentials (subtracting $r$ of seston treatment from $r$ of seston + chlorophytes) would measure the food limitation for population growth. Performing a Pearson correlation between the individual growth differentials obtained in this study for all species and seasons, and the population growth differentials calculated with data of Ferrão-Filho et al. (2003), resulted in a significant positive correlation $\left(\mathrm{r}^{2}=0.712\right.$; $p=0.008$; Fig. 7). Therefore, the data on growth bioassays presented here showed the same trend for cladoceran reproduction (Ferrão-Filho et al., 2003), indicating that the seston of lake Monte Alegre was limiting for individual and population growth of cladocerans in all seasons. Fig. 7 also shows a seasonal difference in food limitation, with better performance of cladocerans, in terms of growth and reproduction, in the warm seasons (spring and summer) than in 
winter. In natural populations of lake Monte Alegre, a trend towards larger clutch sizes of $D$. gessneri and
D. ambigua has been always observed in the warm season (Arcifa et al., 1992, 1998; Fileto, 2001).

TABLE 3

Results of one-way ANOVA for the effect of species, treatments, and interactions in the different seasons. Treatments: seston and seston + chlorophytes.

\begin{tabular}{|c|c|c|c|c|c|}
\hline \multicolumn{6}{|c|}{ Spring } \\
\hline Effect & Sum-of-squares & Df & Mean-square & $\mathbf{F}$ & $\mathbf{p}$ \\
\hline Species & 0.001 & 1 & 0.001 & 0.57 & 0.470 \\
\hline Treatments & 0.023 & 1 & 0.023 & 11.73 & 0.009 \\
\hline Treatment $\mathrm{x}$ species & 0.000 & 1 & 0.000 & 0.000 & 0.995 \\
\hline Error & 0.016 & 8 & 0.002 & & \\
\hline \multicolumn{6}{|c|}{ Summer } \\
\hline Species & 0.425 & 3 & 0.142 & 78.00 & 0.000 \\
\hline Treatments & 0.042 & 1 & 0.042 & 23.24 & 0.000 \\
\hline Treatment $x$ species & 0.014 & 3 & 0.005 & 2.50 & 0.096 \\
\hline Error & 0.29 & 16 & 0.002 & & \\
\hline \multicolumn{6}{|c|}{ Winter } \\
\hline Species & 0.007 & 1 & 0.007 & 3.05 & 0.119 \\
\hline Treatments & 0.117 & 1 & 0.117 & 52.30 & 0.001 \\
\hline Treatment $x$ species & 0.000 & 1 & 0.000 & 0.19 & 0.672 \\
\hline Error & 0.018 & 8 & 0.002 & & \\
\hline
\end{tabular}
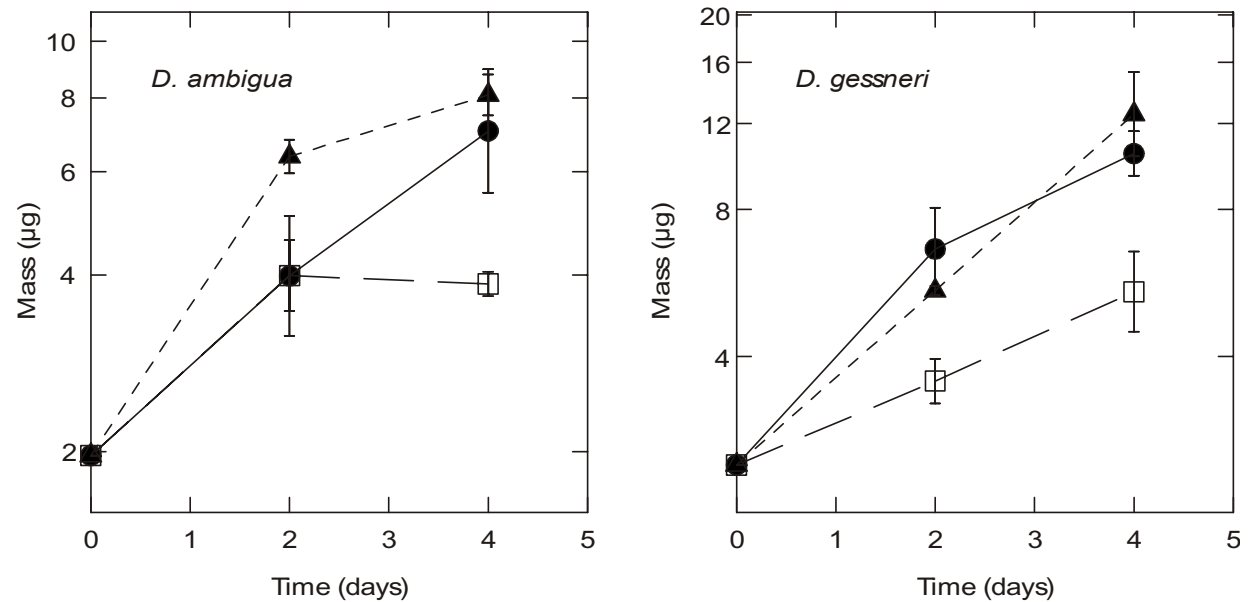

Fig. 4 - Growth bioassay carried out in winter with the cladocerans D. ambigua and D. gessneri in three treatments: $(\bullet)$ Chlorophyte (Scenedesmus spinosus; $\left.1.0 \mathrm{mg} \mathrm{C} \mathrm{L} \mathrm{m}^{-1}\right)$; $(\square)$ seston and $(\boldsymbol{\Delta})$ seston + chlorophyte $\left(0.5 \mathrm{mg} \mathrm{C} \mathrm{L}^{-1}\right)$. 


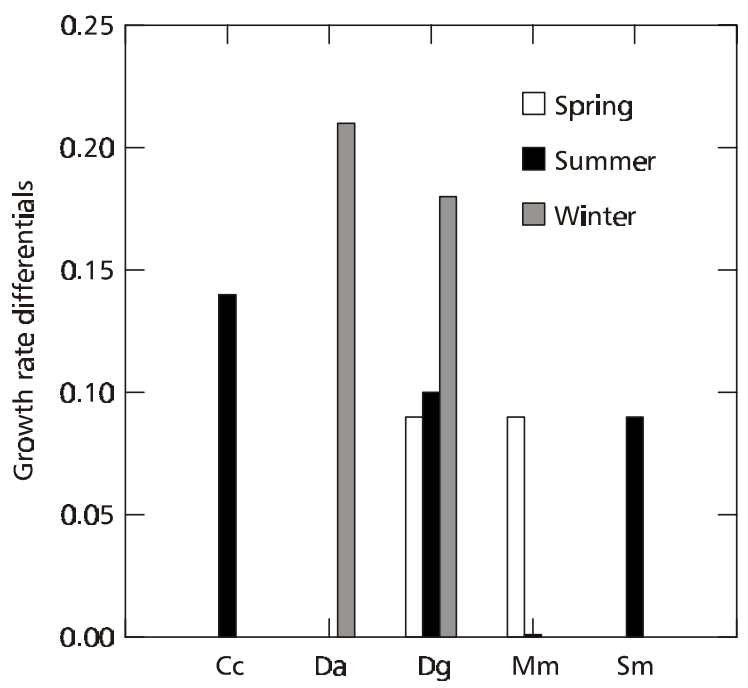

Fig. 5 - Growth rate differentials for cladocerans in the growth bioassays in all seasons. Growth rate differential is the difference in growth rate between seston and seston + chlorophytes treatments. $\mathrm{Cc}=$ Ceriodaphnia cornuta $; \mathrm{Da}=$ Daphnia ambigua $; \mathrm{Dg}=$ Daphnia gessneri; $\mathrm{Mm}=$ Moina micrura $; \mathrm{Sm}=$ Simocephalus mixtus.

In lake Monte Alegre, energy (carbon) seemed to be the most important factor influencing cladoceran growth in winter and summer. In winter, algal carbon concentration $\left(0.04 \mathrm{mg} \mathrm{C} \mathrm{L}^{-1}\right)$ was within the threshold range (0.01-0.05 $\left.\mathrm{mg} \mathrm{C} \mathrm{L}^{-1}\right)$ reported for several Daphnia species (Gliwicz, 1990), including the South American D. gessneri (Hardy \& Duncan, 1994). Nonalgal carbon contribution was also low, but cryptophyceans, known for being high quality food (Ahlgren et al., 1992), comprised 25\% of the algal carbon. Other phytoplankton features representing constraints to cladocerans were also important in that season, such as the relatively higher abundance of inedible dinophyceans. In summer, algal carbon concentration $\left(0.06 \mathrm{mg} \mathrm{C} \mathrm{L}^{-1}\right)$ was close to the threshold level, but particulate carbon concentration was relatively high, and thus other carbon sources such as detritus and bacteria were available to the cladocerans in the lake. Phytoplankton biomass during the experiments in summer was unusually low, relative to the higher values recorded during the same season during a previous study (Arcifa et al., 1998). In spring, algal carbon concentration $\left(0.35 \mathrm{mg} \mathrm{C} \mathrm{L}^{-1}\right)$ was apparently non-limiting to cladocerans, but growth rates were not high compared to those of the other seasons.
However, reproductive performance was better in spring, with higher values of clutch size and fecundity.

Poor ingestion or digestibility of carbon may cause low carbon-transfer efficiency (Wacker \& von Elert, 2001). Actually, part of the algal carbon available in the seston during the experiments could be inedible for cladocerans due to large size, shape, and other algal features. Experiments with Ceriodaphnia cornuta, Daphnia gessneri, and Moina micrura from the lake showed higher population growth and reproductive performance in the nanoplankton $(<20 \mu \mathrm{m})$ compared to the microplankton $(\geq 20 \mu \mathrm{m})$, despite their mutual contamination after net filtration procedure (Fileto et al., 2004). This paper also reports a significant lower growth rate of $M$. micrura in the microplankton. Although during the present study the nanoplankton numerically dominated the phytoplankton, its contribution to the algal carbon was usually low during the experiments: $0.10,0.026$, and $0.023 \mathrm{mg} \mathrm{C} \mathrm{L}^{-1}$, in spring, summer, and winter, respectively. However, according to Burns (1968) and Vanni (1987), $35 \mu \mathrm{m}$ can be the edibility limit for algae, meaning that the available carbon for cladocerans would be higher in the experiments if algae $>20-35 \mu \mathrm{m}$ were included. 

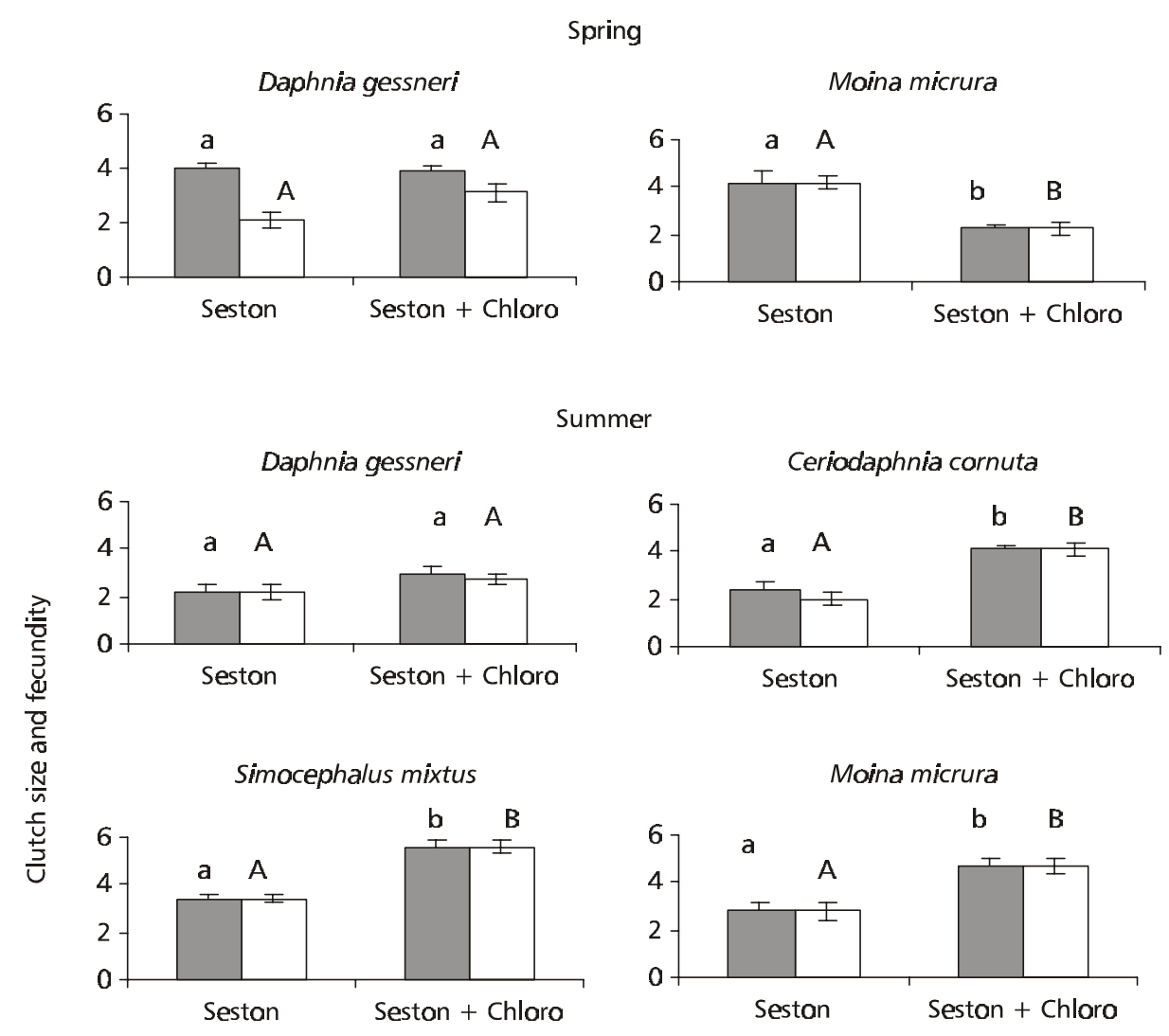

Winter

Daphnia gessneri

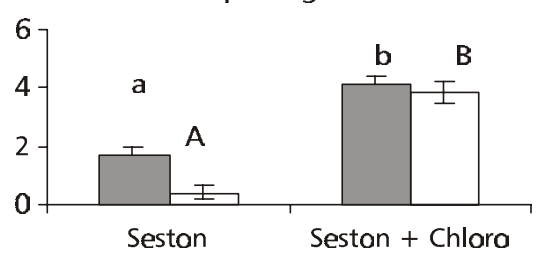

Daphnia ambigua

Clutch size (eggs/ovigerous female)

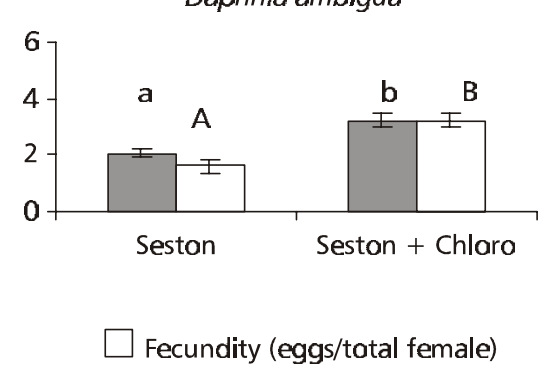

Fig. 6 - Clutch size and fecundity of cladocerans in experiments carried out in the three seasons. Treatments with different letters above error bars (small letter for clutch size and capital one for fecundity) indicate significant differences ( $\mathrm{t}$-test, $\alpha=0.05$ ). 


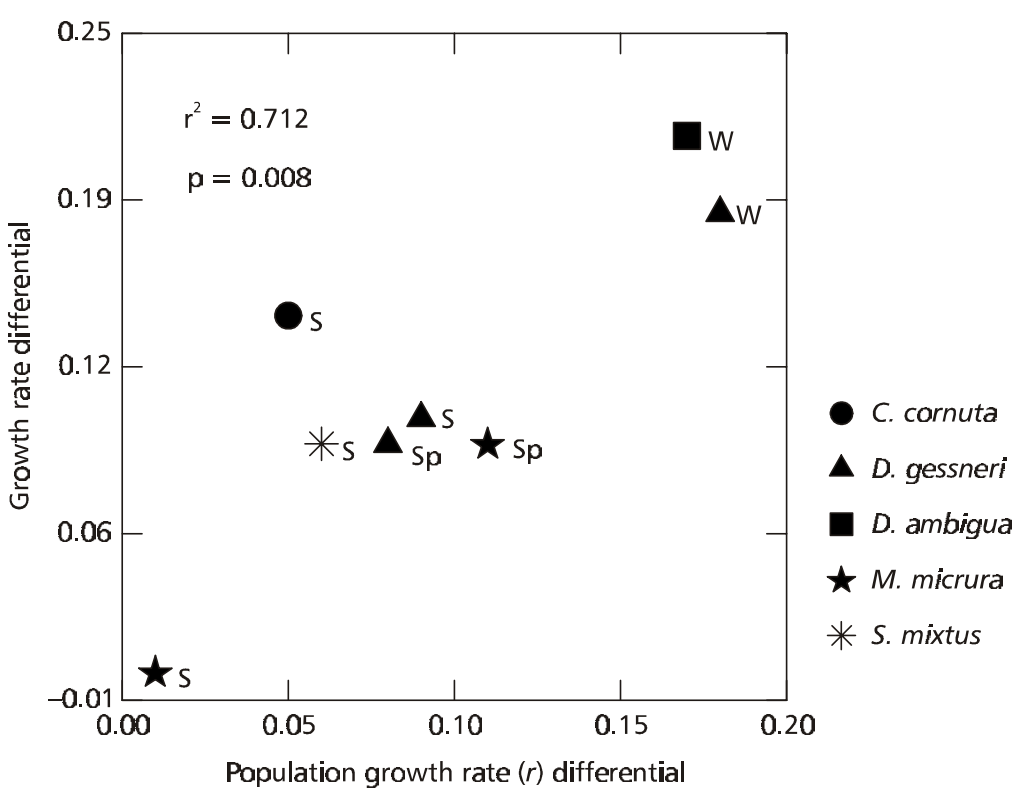

Fig. 7 - Correlation between growth differentials in the bioassays (this study) and population growth differentials (Ferrão-Filho et al., 2003) for all cladocerans in spring, summer and autumn. $\mathrm{Sp}=$ spring; $\mathrm{S}=$ summer; $\mathrm{W}=$ winter.

Apparently, there was also a P-limitation in summer, as the seston molar C:P ratio exceeded the limit of 300 reported by Urabe \& Watanabe (1992). But in lake Monte Alegre, the addition of phosphate to the summer seston with high $\mathrm{C}: \mathrm{P}$ ratio did not improve cladoceran growth in experiments carried out later (Ferrão-Filho \& Arcifa, unpublished). Other experiments with $\mathrm{N}$ and $\mathrm{P}$ added to the lake seston from the four seasons did not enhance cladoceran growth rates in relation to seston alone (Fileto et al., 2004). Thus, the influence of mineral content of algae on cladoceran growth in the lake is questionable. It is possible that a hierarchy exists among factors influencing cladoceran growth, with energy being more important than the P-limitation. If energy is in fact limiting, all possible mineral limitations would be prevented. DeMott \& Tessier (2002), in growth biossays with seston of six North American lakes, suggested that energy limitation would be more important than limitation by sestonic phosphorus and essential fatty acids for Daphnia growth. Their hypothesis that algae digestibility plays an important role, which leads to energy limitation, is supported by a positive correlation between individual growth rate and food assimilation efficiency.
Actually, in spite of all the literature on the importance of fatty acids in algal food for herbivores, there is no consensus among authors that essential fatty acids can limit zooplankton in nature. Experiments with addition of PUFA to seston showed a nonsignificant effect on growth and reproduction of cladocerans from lake Monte Alegre (Ferrão-Filho \& Arcifa, unpublished). Despite a higher algal carbon concentration in spring, growth rates of cladocerans were higher in summer or similar to that observed with the spring and summer seston. In comparison with what happened in the spring, dinophyceans virtually disappeared in summer, increasing the contribution of high-quality cryptomonads. Thus, algae composition, as well as other carbon sources, made summer seston, in spite of its lower algal carbon content, as suitable as or better than spring seston for cladoceran growth.

Differences in life history are evident when comparing Moina micrura with the other cladocerans. Ferrão-Filho et al. $(2000,2003)$ and this study showed that this species allocates more energy for reproduction, starting egg production earlier (2 days) than the others (4 days). However, in the lake M. micrura is not a frequent and successful species, appearing sporadically in periods of low densities of Daphnia 
gessneri, which is commonly the dominant cladoceran in lake Monte Alegre (Arcifa et al., 1992, 1998; Fileto, 2001). Differences in threshold food concentration among cladoceran species can also partially explain this fact, since $M$. micrura has higher food-quantity requirements than the other species (Romanovsky, 1985).

In conclusion, this study supports the hypothesis of food limitation for cladoceran population growth in lake Monte Alegre suggested by Ferrão-Filho et al. (2003). Quali- and quantitative aspects of phytoplankton may cause more constraints for cladocerans in the cool season (winter) than in the warm seasons (spring, summer), corroborating the conceptual model presented by Arcifa et al. (1992) that explains zooplankton population fluctuations in Lake Monte Alegre.

Acknowledgements - We thank Lucia Helena Sampaio da Silva for providing phytoplankton data, W. R. DeMott for valuable suggestions on an earlier draft, and Lourdes M. A. ElmoorLoureiro for identifying Simocephalus mixtus. We also thank FAPESP for a research grant to MSA (97/10407-6) and for grants to ASFF (98/12999-0) and CF (98/14823-7).

\section{REFERENCES}

AHLGREN, G., GUSTAFSSON, I-B. \& BOBERG, M., 1992, Fatty-acid content and chemical composition of freshwater microalgae. J. Phycol., 28: 37-50.

ARCIFA, M. S., 1999, Lago Monte Alegre: uma visão sobre a estrutura e hipóteses de funcionamento. pp. 55-76. In: R Henry (ed.), Ecologia de reservatórios: estrutura, função e aspectos sociais. Fundibio/Fapesp, Botucatu, S. Paulo.

ARCIFA, M. S., MESCHIATTI, A. J. \& GOMES, E. A. T., 1990, Thermal regime and stability of a tropical shallow reservoir: Lake Monte Alegre, Brazil. Rev. Hydrobiol. Trop., 23: 271281.

ARCIFA, M. S., GOMES, E. A. T. \& MESCHIATTI, A. J., 1992, Composition and fluctuations of the zooplankton of a tropical Brazilian reservoir. Arch. Hydrobiol., 123: 479-495.

ARCIFA, M. S., SILVA, L. H. S. \& SILVA, M. H. L., 1998, The planktonic community in a tropical Brazilian reservoir: composition, fluctuations and interactions. Rev. Brasil. Biol., 58: 241-254.

BOERSMA, M., SHOPS, C. \& MCCAULEY, E., 2001, Nutritional quality of seston for the freshwater herbivore Daphnia galeata $\mathrm{x}$ hyalina: biochemical versus mineral limitations. Oecologia, 129: 342-348.

BOZELLI, R. L., 1998, The influence of bauxite tailings on the functional response of carbon incorporation rates of three species of tropical cladocerans. Verh. Int. Ver. Limnol., 26: 1894-1897.
BUNIOTO, T. C., 2003, Variação temporal e distribuição horizontal do zooplâncton no lago Monte Alegre e a influência do alimento e da temperatura sobre cladóceros. Dissertação de Mestrado, FFCLRP/USP, Ribeirão Preto, 96p.

BURNS, C. W., 1968, The relationship between body size of filter-feeding Cladocera and the maximum size of particles ingested. Limnol. Oceanogr., 13: 675-678.

CASSANO, C. R., CASTILHO-NOLL, M. S. M. \& ARCIFA, M. S., 2002, Water mite predation on zooplankton in a tropical Brazilian lake. Braz. J. Biol., 62(4A): 565-571.

CASTILHO-NOLL, M. S. M., 2002, A predação de larvas de Chaoborus brasiliensis sobre populações zooplanctônicas. Tese de Doutorado, IB/USP, São Paulo, 101p.

DeMOTT, W. R. \& MÜLLER-NAVARRA, D. C., 1997, The importance of highly unsaturated fatty acids in zooplankton nutrition: evidence from experiments with Daphnia, a cyanobacterium and lipid emulsions. Freshwater Biol., 38 : 649-664.

DeMOTT, W. R. \& GULATI, R. D., 1999, Phosphorus limitation in Daphnia: evidence from a long-term study of three hypereutrophic Dutch lakes. Limnol. Oceanogr., 44: 15571564.

DeMOTT, W. R., GULATI, R. D. \& DONK, E. VAN, 2001, Effects of dietary phosphorus deficiency on the abundance, phosphorus balance, and growth of Daphnia cucullata in three hypereutrophic Dutch lakes. Limnol. Oceanogr., 46: 1871-1880.

DeMOTT, W. R. \& TESSIER, A. J., 2002, Stoichiometric constraints vs. algal defences: testing mechanisms of zooplankton food limitation. Ecology, 83: 3426-3433.

ELSER, J. J., HAYAKAWA, K. \& URABE, J., 2001, Nutrient limitation reduces food quality for zooplankton: Daphnia response to seston phosphorus enrichment. Ecology, 82: 898903.

FASSBENDER, H. W., 1973, Simultane P-Bestimmung in NKjeldahl-AusfschluB von Bodenproben. Die Phosphorsäure, 30: 40-53.

FERRÃO-FILHO, A. S., AZEVEDO, S. M. F. O. \& DEMOTT, W. R., 2000, Effects of toxic and non-toxic cyanobacteria on the life history of tropical and temperate cladocerans. Freshwater Biol., 43: 1-19.

FERRÃO-FILHO, A. S., ARCIFA, M. S. \& FILETO, C., 2003, Resource limitation and food quality for cladocerans in a tropical Brazilian lake. Hydrobiologia, 491: 201-210.

FILETO, C., 2001, O zooplâncton do lago Monte Alegre: variação temporal e a influência das frações do fitoplâncton sobre o crescimento e reprodução de cladóceros. Dissertação de Mestrado, FFCLRP/USP, 100p.

FILETO, C., ARCIFA, M. S., FERRÃO-FILHO, A. S. \& SILVA, L. H. S., 2004, Influence of phytoplankton fractions on growth and reproduction of tropical cladocerans. Aquat. Ecol., 38: 503-514.

GLIWICZ, Z. M., 1990, Food thresholds and body size in cladocerans. Nature, 343: 638-640. 
GULATI, R. D. \& DeMOTT, W. R., 1997, The role of food quality for zooplankton: remarks on the state-of-the-art, perspectives and priorities. Freshwater Biol., 38: 753-768.

HARDY, E. R. \& DUNCAN, A., 1994, Food concentration and temperature effects on life-cycle characteristics of tropical Cladocera Daphnia gessneri Herbst, Diaphanosoma sarsi Richard, and Moina reticulata Daday. I. Development time. Acta Amazonica, 24: 119-134.

KURMAYER, R., 2000, Nutritive versus interfering effects of Anabaena on Daphnia and Ceriodaphnia. Verh. Int. Ver. Limnol., 27: 1-4.

KURMAYER, R., 2001, Competitive ability of Daphnia under dominance of non-toxic filamentous cyanobacteria. Hydrobiologia, 442: 279-289.

LAMPERT, W., 1987, Feeding and nutrition in Daphnia. pp. 143-192. In: R. H. Peters \& R. De Bernardi (eds.), Daphnia. Mem. Ist. Ital. Idrobiol, 45. Verbania, Pallanza.

LORENZEN, C. F., 1967, Determination of chlorophyll and pheopigments: spectrophotometric equations. Limnol. Oceanogr., 16: 990-992.

MACKERETH, F. J. H., HERON, J. \& TALLING, J. F., 1978, Water analysis: some revised methods for limnologists. Freshwater Biological Association Scientific Publication n. 36, Cumbria and Dorser, England, 120p.

MÜLLER-NAVARRA, D. C., 1995, Evidence that a highly unsaturated fatty acid limits Daphnia growth in nature. Arch. Hydrobiol., 132: 297-307.

MÜLLER-NAVARRA, D. C., BRETT, M. T., LISTON, A. M. \& GOLDMAN, C. R., 2000, A highly unsaturated fatty acid predicts carbon transfer between primary producers and consumers. Nature, 401: 74-77.

NANDINI, S., 2000, Responses of rotifers and cladocerans to Microcystis aeruginosa (Cyanophyceae): a demographic study. Aquat. Ecol., 34: 227-242.

PINTO-COELHO, R. M., 1998, Effects of eutrophication on seasonal patterns of mesozooplankton in a tropical reservoir: a 4-year study in Pampulha lake, Brazil. Freshwater Biol., 40: 159-173.
ROMANOVSKY, Y. E., 1985, Food limitation and life-history strategies in cladoceran crustaceans. Arch. Hydrobiol. Beih. Ergebn. Limnol, 21: 363-372.

SILVA, L. H. S., 1995, Variabilidade temporal na estrutura da comunidade planctônica de um reservatório eutrófico - Lago Monte Alegre, Ribeirão Preto, São Paulo, Brasil. Dissertação de Mestrado, URFJ, Rio de Janeiro, 141p.

STEMBERGER, R. S., 1981, A general approach to the culture of planktonic rotifers. Can. J. Fish. Aquat. Sci., 38: 721724.

STERNER, R. W. \& SCHULZ, K. L., 1998, Zooplankton nutrition: recent progress and a reality check. Aquat. Ecol., 32: 261-279.

STRICKLAND, J. D. H. \& PARSONS, T. R., 1972, A practical handbook of seawater analysis. Bulletin of Fishery Research. Bd., Canada, 310p.

URABE, J. \& WATANABE, Y., 1992, Possibility of N or P limitation for planktonic cladocerans: an experimental test. Limnol. Oceanogr., 37: 244-251.

UTERMÖHL, H., 1958, Zur Vervollkommung der quantitativen Phytoplankton-Methodik. Mitt. Int. Ver. Limnol., 9: 1-38.

VANNI, M. J., 1987, Effects of food availabity and fish predation on a zooplankton community. Ecological Monographs, 57: 61-68.

VOLLENWEIDER, R. A., 1974, A manual on methods for measuring primary production in aquatic environments. IBP Handbook 12, $2^{\text {nd }}$ ed. Blackwell Scientific Publications, London, 213p.

WACKER, A. \& von ELERT, E., 2001, Polyunsaturated fatty acids: evidence for non-substitutable biochemical resources in Daphnia galeata. Ecology, 82: 2507-2520. 